\title{
Incorporation of Ceramic Waste into Binary and Ternary Soil-Cement Formulations for the Production of Solid Bricks
}

\author{
Vamberto Monteiro da Silva ${ }^{a}$, Luciano Costa Góis ${ }^{a}$, João Batista Duarte ${ }^{a}$, \\ Jaquelígia Brito da Silva ${ }^{b}$, Wilson Acchar ${ }^{a *}$ \\ ${ }^{a}$ Graduate Program in Materials Science and Engineering - PPGCEM, Federal University of \\ Rio Grande do Norte - UFRN, CEP 59072-970, Natal, RN, Brazil \\ ${ }^{b}$ Graduate Program in Civil Engineering - PEC, Federal University of Rio Grande do Norte - UFRN, \\ CEP 59072-970, Natal, RN, Brazil
}

Received: March 18, 2013; Revised: November 7, 2013

\begin{abstract}
The incorporation of ceramic waste $(\mathrm{CW})$ into solid bricks made with soil-cement mixtures has been studied in recent years. The aim of this study was to evaluate the physical and mechanical properties of solid bricks made with soil-cement mixtures uniaxially pressed with the addition of construction waste, having hydrated lime and CPII F-32 Portland cement as binding agents to be used in formulations. Raw materials were characterized by particle size analysis, Atterberg limits, XRF and XRD. Solid bricks were made with soil-cement mixtures and $\mathrm{CW}$, which were cured for 7, 28 and 56 days and submitted to compressive strength, water absorption and modified durability tests. The best results obtained were for percentages of $12 \%$ cement and $4 \%$ incorporated CW.
\end{abstract}

Keywords: soil-cement mixtures, ceramic waste, physicochemical characterization, technological properties

\section{Introduction}

In recent decades, issues related to environmental preservation, waste reduction and recycling have occupied a prominent place in discussions held by society seeking to achieve a sustainable development model for the planet.

In Brazil, the concern with the reuse of solid waste is relatively recent, but the recycling of construction and demolition waste (CDW) is in an advanced stage of discussion by various sectors of civil society in order to seek solutions to minimize the problem. Studies have shown that approximately 40 to $70 \%$ of urban wastes come from the construction industry, and that materials discarded at construction sites are composed of $64 \%$ mortar, 30\% components used in sealing (bricks, tiles and ceramic blocks) and 6\% other materials (concrete, stones, sand and metallic materials) ${ }^{1}$. Among the many factors that contribute to CDW generation, the lack of defined and detailed projects and the absence of operational procedures and mechanisms to control the implementation and inspection of construction works stand out.

$\mathrm{CDW}$ processing brings significant benefits to the environment, since when finely ground, CDW may have pozzolanic activity and could be applied with lime as partial substitute for Portland cement in the production of mortars and concretes ${ }^{2}$. The application of these pozzolanic materials significantly reduces the emission of gases into the atmosphere, since they may be partially used as substitute for binding agents.

\footnotetext{
*e-mail: acchar@gmail.com
}

The production of soil-cement bricks added of CDW is inserted within the context of sustainable development currently in the construction industry, whose basic principle is supported by planned economic growth, environment preservation and search for a better quality of life through social inclusion. Recently, studies on this topic have been carried out to better understand the cementitious and pozzolanic reactions that occur in the formation of the soilcement system microstructure when various materials are added, including ceramic waste $(\mathrm{CW})$, and the relationship between its microstructure and interfaces with the physical, mechanical and chemical properties found in compounds made from these mixtures ${ }^{3}$.

Studies carried out in Ilha Solteira (SP) in the past decade showed promising results in the process of incorporating waste from mortar (cement and sand) and concrete for the production of soil-cement bricks. Akasaki produced soillime bricks with the addition of agro-industrial wastes (rice husk, sawdust and sugarcane bagasse), achieving significant results for the mixture with 5\% rice husk. Other scientific studies have succeeded in incorporating granite cutting (Campina Grande, PB/2010) and termite mound wastes (Cassilândia, MS/2006).

Considering all the factors previously mentioned, $\mathrm{CW}$ from construction and brickworks, when comminuted, is a material qualified as pozzolanic, which could be used as an additive in soil stabilization processes 3 . The aim of this study was to evaluate the microstructure and the physical and mechanical properties of soil-cement bricks added of 
different amounts of $\mathrm{CW}$ and binding agents (Portland cement and / or lime) for different curing periods.

\section{Material and Methods}

The soil used in the composition of the soil-cement mixture was collected at the BR-101 highway (Km 126), stretch between municipalities of São José de Mipibú and Goianinha, RN, Brazil. This is an A-6 soil, whose geotechnical characteristics are representative of lateritic tropical soils typical of the State of Rio Grande do Norte. The cement applied was CP II F-32, which has properties consistent with recommendations of the Brazilian Association of Portland Cement (ABCP) for the preparation of soil-cement compositions. HL-II calcium hydrated lime was used, as recommended by the Brazilian Association of Lime Producers (ABPC), manufactured in the city of Campina Grande, PB. CW was collected from small and medium-size civil works in the city of Natal, RN, from ceramic bricks manufactured in the "Ouro Branco" pottery, located at the municipality of Ielmo Marino, RN. After collection, soil was submitted to process of natural drying in covered place protected from the action of wind and rain, and then ground and sieved in $4.8 \mathrm{~mm}$ mesh (\# 4), and packaged in PVC containers with capacity of 50 liters, protected from the action of moisture. After collection, drying and grinding steps, retraction test was performed to assess the expansion, contraction and plasticity characteristics, which are intended to visually identify the presence of transverse cracks in the central part of the sample exceeding the limit of $2.0 \mathrm{~cm}$, which suggests the presence of expansive clay. CW was fragmented in a Q298 ball mill and sieved in mesh \# 200 $(75 \mu \mathrm{m})$ and $325(45 \mu \mathrm{m})$, respectively. After grinding and sieving, the material was placed in plastic bags to protect from the action of moisture.

The materials used were submitted to characterization tests by X-ray Fluorescence (XRF), Spectrometry (Shimadzu EDX-700), and X-ray Diffraction (XRD), (shimadzu XRD-6000), to determine the chemical composition and identify the mineralogical phases, respectively. Then, soil and $\mathrm{CW}$ samples were prepared to undergo compression and characterization tests ${ }^{4}$ to determine the moisture content and soil particle size ${ }^{5}$. The soil specific mass ${ }^{6}$ was determined using grains present in sieve \# 4 (4.8 $\mathrm{mm})$. Following particle size analysis of soil and CW, plasticity indexes were determined through the Atterberg limits (liquid and plastic limits), which express the workability level ${ }^{7}$. Then, soil compaction test ${ }^{8}$ was performed, which aimed to determine the optimal moisture content and maximum dry apparent specific weight. After characterization of raw materials, formulations for the manufacture of specimens were prepared. CW percentages relative to soil mass of $2 \%$ and $4 \%$ were added, and for soil chemical stability, percentages of binding agents in relation to the soil mass of $8 \%, 10 \%$ and $12 \%$ were added, respecting the minimum value recommended of $6 \%{ }^{[9]}$. The maximum binding agent percentage of $12 \%$ in relation to the soil mass was established according to the economic viability for solid brick production. Procedure similar to that applied in the soil compaction test was applied in soil-cement and CW compositions ${ }^{10}$. Ternary and quaternary soil-cement and CW mixtures for moulding solid bricks ${ }^{11}$ were defined according to results obtained in previous works. For each composition selected, twenty solid bricks were pressed, twelve for the compressive strength test ${ }^{12}$, three for water absorption test ${ }^{12}$ and five for the modified durability test. These mixtures were mechanically mixed using a Motomil-MB-150L mixer. Solid bricks were produced in a manual press with load capacity of two MPa (Sahara Hobby) to obtain bricks with thickness of $5.0 \mathrm{~cm}$, width of $10.0 \mathrm{~cm}$ and length of $21.0 \mathrm{~cm}$. The specimens were submitted to curing process by spray water in a moist chamber for periods of 07, 28 and 56 days $^{12}$.

Tests were carried out to determine the water absorption capacity of soil-cement and CW solid bricks, according to NBR 8492/84[12].

Assays were performed to determine the compressive strength of soil-cement and CW bricks, according to NBR 8492/84.

Finally, modified durability tests were performed according to DNER-ME 203/94 ${ }^{[13]}$.

The modified durability assay consists of twelve drying cycles in oven and immersion in water, without the need for brushing the bricks. The scientific literature justifies that requests of superficial abrasion that sealing bricks are submitted are less stringent than those found in road works, and the brushing step is not necessary.

\section{Results and Discussion}

Table 1 shows the chemical composition of raw materials used. The soil used has high silica $\left(\mathrm{SiO}_{2}\right)$ and alumina contents $\left(\mathrm{Al}_{2} \mathrm{O}_{3}\right)$, which indicate strong presence of quartz and kaolinite minerals, according to X-ray diffraction results (Figure 1).

Hydrated lime presents high calcium oxide content $(88.3 \%)$ and intermediate magnesium oxide content $(6.43 \%)$, being classified as HL-II-type calcium lime, according NBR $7175 / 2003^{[14]}$ Figure 2 shows the lime XRD and the presence of Calcite, Portlandite and Brucite phases.

The cement used shows high percentage of calcium oxide (Table 1), with the presence of Calcite, Dolomite, Quartz and Hatruite mineralogical phases (Figure 3).

Table 1. Chemical composition of soil, waste and binding agents.

\begin{tabular}{lrrrrrrrr}
\hline \multicolumn{1}{c}{ Oxides \% } & $\mathbf{S i O}_{2}$ & $\mathbf{A l}_{2} \mathbf{O}_{3}$ & $\mathbf{F e}_{2} \mathbf{O}_{3}$ & $\mathbf{M g O}$ & $\mathbf{C a O}$ & $\mathbf{K}_{2} \mathbf{O}$ & $\mathbf{N a}_{2} \mathbf{O}$ & $\mathbf{Z r O}_{2}$ \\
\hline Soil & 52.20 & 36.00 & 1.91 & 0.49 & 0.00 & 0.25 & 0.00 & 0.09 \\
Cement & 19.03 & 4.60 & 3.22 & 3.20 & 60.84 & 1.22 & 0.15 & 0.00 \\
Hydrated Lime & 2.31 & 0.75 & 0.47 & 6.43 & 88.30 & 0.12 & 0.00 & 0.00 \\
CW & 45.59 & 35.69 & 7.82 & 4.11 & 1.46 & 2.38 & 0.97 & 0.06 \\
\hline
\end{tabular}


Ceramic waste $(\mathrm{CW})$ has high silica, aluminum oxide and iron oxide contents, accounting for about $89.1 \%$ of its composition. This result exceeds the minimum value of $70 \%$ of the sum of oxides for Class $\mathrm{N}$ pozzolan materials, recommended by the respective standard ${ }^{15}$. CW diffractogram shows quartz, phlogopite and anorthite phases, as shown in Figure 4.

The particle size analysis shows that the amount of soil and CW sieved through sieve \# 4 (4.8 $\mathrm{mm}$ ) reaches values of $97.73 \%$ and $99.92 \%$ respectively, through sieve \# 40 $(0.42 \mathrm{~mm}), 85.31 \%$ and $90.93 \%$, respectively and through

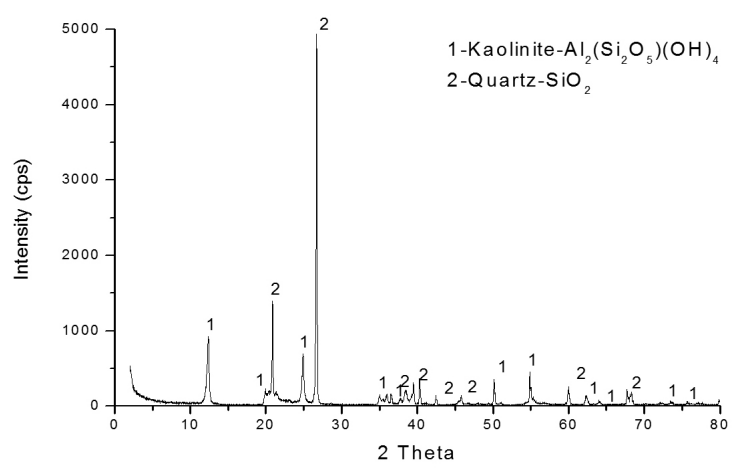

Figure 1. Soil XRD.

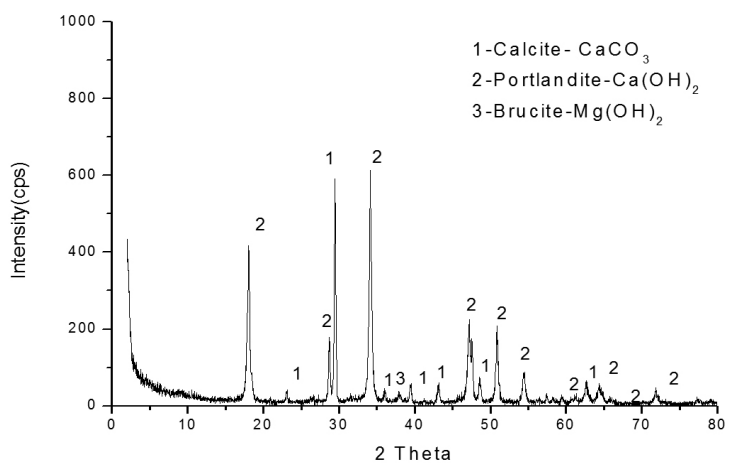

Figure 2. Lime XRD.

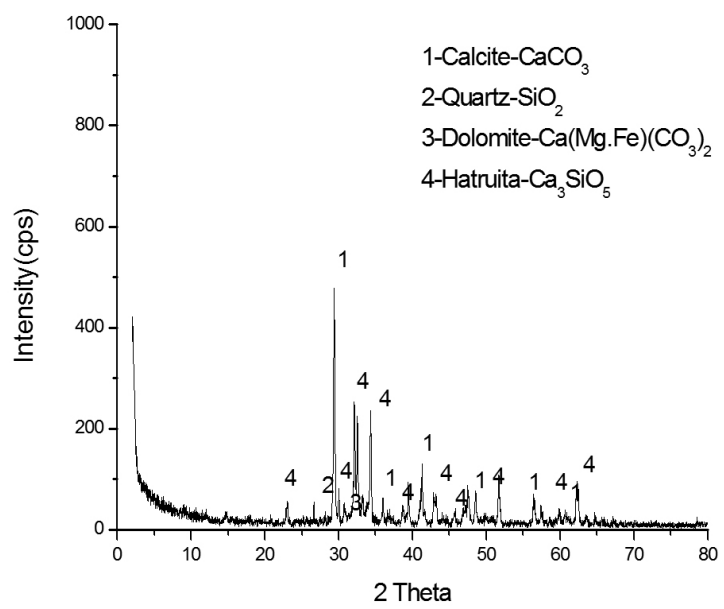

Figure 3. Cement XRD. sieve \# $200(0.075 \mathrm{~mm})$ the percentage is around $47.70 \%$ and $66.43 \%$, respectively. The analysis of results reveals that the soil selected meets parameters set by ABCP for soil-cement mixtures, or approximately $100 \%$ of grains being sieved through sieve \# 4, 15 to $100 \%$ being sieved through sieve \# 40 and 10 to $50 \%$ through sieve \# 200. It is noteworthy that the soil chosen also complies with criteria established for the production of soil-cement solid bricks, not requiring grain size correction. As for $\mathrm{CW}$, technical standards recommend ${ }^{16}$ that the smaller the particle size, the larger the specific surface area and reactivity degree with calcium hydroxide in the presence of water. It should be emphasized that percentages of $2 \%$ and $4 \%$ incorporated into the soil fine fraction meet the limits established by this standard, i.e., between $10 \%$ and $50 \%$ of the soil-CW composition sieved through sieve \# 200 (0.075 mm).

Table 2 shows the results of the Atterberg limits (liquid limit, plastic limit and plasticity index) and specific mass of solids, soil and soil-CW (SCW).

The results shown in Table 2 indicate that the soil can be classified as moderately plastic $(7<\mathrm{PI}<15)$. It is noteworthy that the soil used meets the standard, which establishes the maximum limit of $45 \%$ for LL and $18 \%$ for LP. The result of the retraction test performed in the soil sample collected did not show transverse cracks in its central portion exceeding the limit of $2.0 \mathrm{~cm}$, and cracks were smaller than $1.0 \mathrm{~cm}$, confirming the absence of expansive clay, which is in agreement with the plasticity results shown above. In determining the Atterberg limits for the soil-waste mixture, experimental tests were performed incorporating $\mathrm{CW}$ percentages in relation to the soil mass. The maximum limit of $\mathrm{CW}$ incorporation to the soil was estimated in decreasing order from $50 \%$, with the aim of determining the range of waste additions that do not exceed liquid and plastic limits recommended by the standard. The tests performed showed that the range from 2 to $4 \% \mathrm{CW}$ added to the soil mass kept the Atterberg limits in accordance with this standard.

The maximum dry apparent specific weight and optimal moisture values of soil-cement, soil-cement-hydrated lime and CW compositions were determined by standard compression test, and are shown in Table 3. For formulated compositions, the following terminology was adopted:

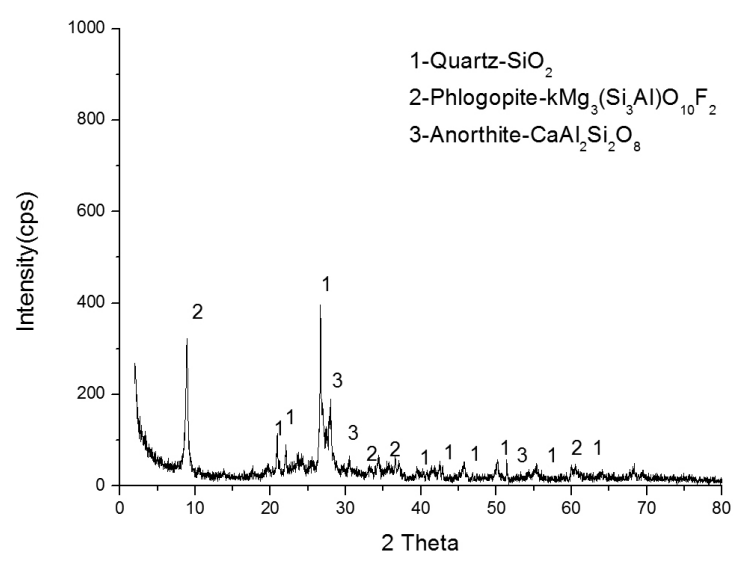

Figure 4. CW XRD. 
Table 2. Atterberg Limits / Specific mass of soil and CW.

\begin{tabular}{ccccc}
\hline Atterberg Limits / Specific mass & S & S2CW & S4CW & S5CW \\
\hline Liquid Limit & $28.40 \%$ & $28.60 \%$ & $29.50 \%$ & $30.12 \%$ \\
Plastic Limit & $17.80 \%$ & $17.85 \%$ & $17.98 \%$ & $18.11 \%$ \\
Plasticity Index & $10.60 \%$ & $10.75 \%$ & $11.52 \%$ & $12.01 \%$ \\
$\gamma_{\text {soil }}$ & $2.49 \mathrm{~g} / \mathrm{cm}^{3}$ & - & - & - \\
$\gamma_{\mathrm{CW}}$ & $2.65 \mathrm{~g} / \mathrm{cm}^{3}$ & - & - & - \\
\hline
\end{tabular}

Table 3. Maximum dry apparent specific weight and $\mathrm{H}_{\mathrm{ot}}$ of soilcement and $\mathrm{CW}$ compositions.

\begin{tabular}{lll}
\hline \multicolumn{1}{c}{ Compositions } & \multicolumn{1}{c}{$\gamma_{\text {smax }}\left(\mathbf{g} / \mathbf{c m}^{3}\right)$} & $\mathbf{H}_{\text {ot }}(\boldsymbol{\%})$ \\
\hline $\mathrm{S}$ & 1.84 & 14.81 \\
$\mathrm{~S} 8 \mathrm{C} 2 \mathrm{CW}$ & 1.80 & 15.48 \\
S8C4CW & 1.81 & 15.15 \\
S10C2CW & 1.78 & 16.15 \\
S10C4CW & 1.79 & 16.06 \\
S12C2CW & 1.82 & 14.87 \\
S12C4CW & 1.83 & 14.85 \\
S7C3HL2CW & 1.78 & 16.12 \\
S8C2HL2CW & 1.79 & 16.10 \\
S10C2HL2CW & 1.82 & 14.95 \\
S10HL2CW & 1.72 & 16.98 \\
S12HL2CW & 1.71 & 17.10 \\
\hline
\end{tabular}

$\mathrm{S}=$ soil, $\mathrm{C}=$ cement, $\mathrm{HL}=$ hydrated lime and $\mathrm{CW}=$ ceramic waste.

Data in Table 3 show that soil-cement and CW mixtures had an average increase in optimal moisture content with respect to that obtained for soil. The results obtained are due to the incorporation of the fine portion from cement, lime and $\mathrm{CW}$, leading to an average increase of the specific surface of particles present in the mixtures and greater demand for water in the compression and molding stages to obtain maximum dry specific weight close to that obtained for soil. The addition of water to obtain optimal moisture content during compaction contributes to increase the presence of voids in the soil-cement and $\mathrm{CW}$ mixture, resulting in higher porosity level and decreased maximum dry specific weight for the same compaction energy applied.

Figures 5 and 6 show the compressive strength variation in relation to soil-cement, soil-cement-hydrated lime and $\mathrm{CW}$ compositions used in the production of bricks. The analysis of results indicates that $\mathrm{S} 12 \mathrm{C} 4 \mathrm{CW}$, S12C2CW and S10C2HL2CW formulations showed the best compressive strength results. This fact confirms that in soil-cement and CW formulations, the addition of $2 \%$ CW together with other phases present in the hydration of Portland cement, namely sulfates and aluminates, as well as calcium hydroxide, produced from $\mathrm{C}_{2} \mathrm{~S}$ and $\mathrm{C}_{3} \mathrm{~S}$ hydration, accelerated the pozzolanic reaction kinetics and increased the compressive strength. In the soil-cement-lime and $\mathrm{CW}$ (S10C2HL2CW) composition, the elevation in the calcium hydroxide level of the mixture requires a longer curing time so that the mechanisms involved in the pozzolanic reaction occur. As regards to the compressive strength of bricks,

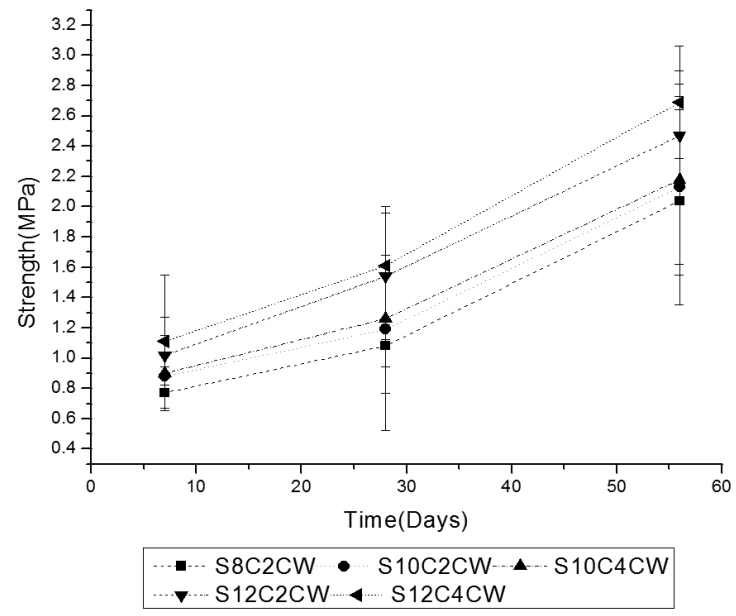

Figure 5. Strength of soil-cement and CW bricks.

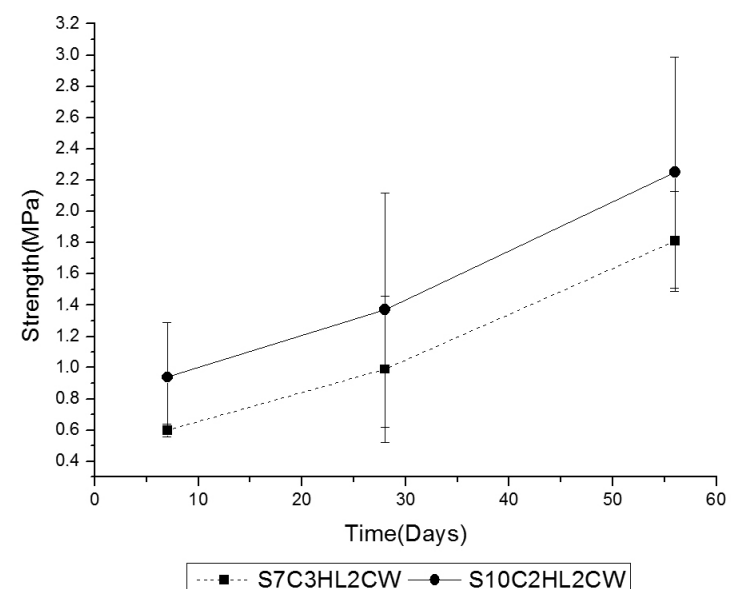

Figure 6. Strength of soil-cement-lime and CW bricks.

based on data obtained for moulded compositions, it was found that the average values of compositions broken at 56 days reached parameters established by the standard ${ }^{17}$, confirming the pozzolanic effect resulting from the reaction of calcium hydroxide with the unorganized structure of silicates and aluminates of $\mathrm{CW}$ and mineral clays in the soil over time. It is noteworthy that in soil-cement bricks without structural purposes, the minimum strength required is $1.0 \mathrm{MPa}^{[18]}$.

Figure 7 shows the results obtained in the water absorption test. It was found that all soil-cement and CW 


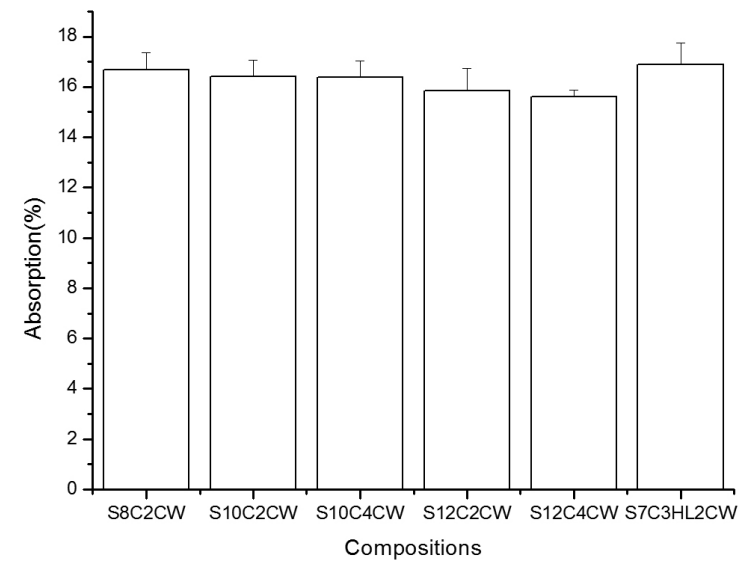

Figure 7. Water absorption values of soil-cement-lime and CW bricks.

compositions met limits established by NBR 8492, i.e., the sample tested must not show mean water absorption values greater than $20 \%$, or individual values greater than $22 \%$. Incorporating $\mathrm{CW}$ percentages in soil-cement and soil-cement-lime formulations provided a reduction in porosity, resulting from the short-term micro-filler effect. Furthermore, the pozzolanic effect is potentiated by the unorganized structure of silicates and aluminates present in $\mathrm{CW}$, in the long-term contributing to increase cohesion between particles and densification of mixtures. The data obtained confirm the relationship between physicomechanical properties (compressive strength and water absorption) and densification and porosity of compositions, since solid bricks made from soil-cement-lime and soil-cement-lime and $\mathrm{CW}$ mixtures reached the highest mechanical strength and lowest water absorption values.

Comparing the values obtained in the water absorption and compressive strength assays with the experimental results of other scientific studies that incorporated wastes such as: rice husk, mortar and concrete, which reached values of $18.67 \% 22.20 \%, 13.30 \%$, respectively, for water absorption and values of $1.18 \mathrm{MPa}, 1.73 \mathrm{MPa}$ and $8.12 \mathrm{MPa}$ for compression strength at fifty-six days, it was found that some compositions incorporated with the addition of ceramic waste showed more significant results than those that incorporated rice husk and mortar wastes.

The modified durability test was applied to solid bricks adapting to the precepts established in the DNER ME 203/94 test method and limits set by NBR $13553 / 96^{19}$. The results are shown in Figure 8.

As can be seen, the mass loss percentage of soil-cement and $\mathrm{CW}$ formulations decreased with increasing $\mathrm{CW}$ and Portland cement concentrations in mixtures. These results are justified by cementitious reactions and the micro-filler effect provided by the fineness of $\mathrm{CW}$, which contribute to greater densification and reduced porosity of compositions. The S7C3HL2CW mixture showed the highest mass loss percentage compared to the results of other formulations. This fact may be correlated with the carbonation phenomenon that affects the pozzolanic reactions between calcium hydroxide and the disordered
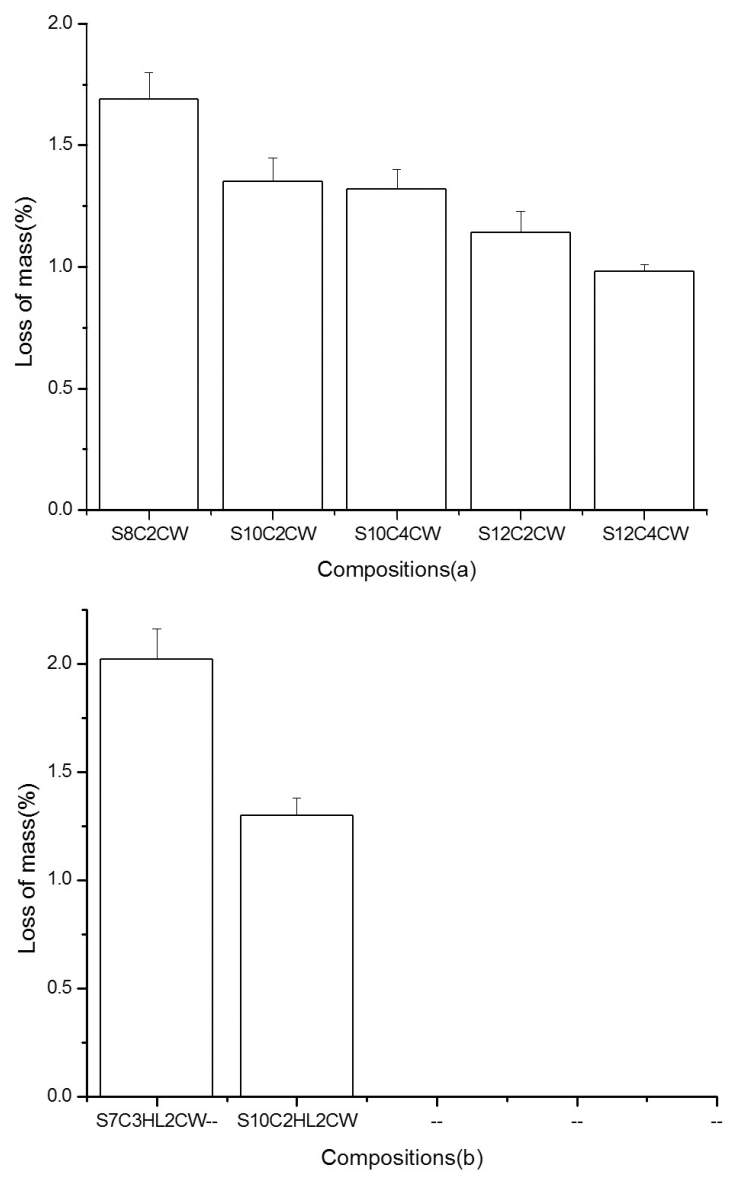

Figure 8. Mass loss of soil-cement-lime and CW solid bricks (a) and (b).

arrangement of silicates and aluminates present in CW and soil, contributing to increased porosity and decreased densification of this composition. Finally, it appears that all soil-cement-lime and soil-cement-lime-CW mixtures used to produce solid bricks reached the limits established by standard ${ }^{19}$ for mass loss, since mass loss after wetting and drying cycles for A-6 soils may not exceed 7\%. It is noteworthy that for soil-cement bricks without structural purposes, the maximum allowable mass loss is $10 \%{ }^{[19]}$, based on $\mathrm{ABCP}$ recommendations.

\section{Conclusion}

The results obtained appeared to be promising for the use of CW as triggering element of pozzolanic reactions in mixtures prepared with soil, lime and cement.

From data obtained from physical, mechanical, chemical and mineralogical tests of the surface crack microstructure, it could be concluded that the incorporation of $2 \%$ and $4 \%$ $\mathrm{CW}$ in soil-cement-lime compositions with percentages of $8 \%, 10 \%$ and $12 \%$ of binding agent confirmed the technical feasibility of $\mathrm{CW}$ in improving the physical and mechanical properties of compositions developed for the production of solid bricks, meeting the provisions of current technical standards for use in brickworks without structural purposes. 


\section{References}

1. Pinto TP. Gestão ambiental dos resíduos da construção civil: A experiência do Sinduscon-SP. São Paulo: Sinduscon, 2005.

2. Hendriks CF. Durable and Sustainable Construction Materials, Aeneas Netherlands. 2000.

3. Dallacort R, Lima HC Jr and Willrich FL. Resistência à compressão do solo-cimento com substituição parcial do cimento Portland por resíduo cerâmico moído. Revista Brasileira de Engenharia Agrícola Ambiental. 2002; 6(3).

4. Associação Brasileira de Normas Técnicas - ABNT. NBR 6457: Preparação de amostras de solo para ensaio normal de compactação e ensaio de caracterização. Rio de Janeiro: ABNT, 1986.

5. Associação Brasileira de Normas Técnicas - ABNT. NBR 7181: Solo - análise granulométrica. Rio de Janeiro: ABNT, 1988 .

6. Associação Brasileira de Normas Técnicas-ABNT. NBR 6508: Grãos de Solos que passam na peneira de 4,8 mm, determinação da massa específica. Rio de Janeiro: ABNT, 1984.

7. American Society for Testing and Materials - ASTM. D 431810: Standard Tests Methods for Liquid Limit, Plastic Limit, and Plasticity index of Soils. ASTM; 2010.

8. Associação Brasileira de Normas Técnicas - ABNT. NBR 7182: Solo - ensaio normal de compactação. Rio de Janeiro: ABNT, 1988.

9. Sherwood PT. Soil Stabilization with cement and lime: State of the Art Review. London: HMSO, 1993.

10. Associação Brasileira de Normas Técnicas - ABNT. NBR 12023: Solo-cimento - ensaio de compactação. Rio de Janeiro: ABNT, 2012.
11. Associação Brasileira de Normas Técnicas - ABNT. NBR 10832: Fabricação de tijolo maciço de solo-cimento com utilização de prensa manual. Rio de Janeiro: ABNT, 1989.

12. Associação Brasileira de Normas Técnicas-ABNT. NBR 8492: Solo-Cimento-tijolos maciços de solo-cimento: determinação da resistência à compressão e da absorção de água. Rio de Janeiro: ABNT, 1984.

13. Departamento Nacional de Estradas e Rodagem - DNER. DNER-ME 203-94: Solo-cimento-Determinação da durabilidade através da perda de massa por molhagem e secagem. DNER;1994.

14. Associação Brasileira de Normas Técnicas-ABNT. NBR 7175: Cal hidratada para argamassas. Rio de Janeiro: ABNT, 2003.

15. Associação Brasileira de Normas Técnicas-ABNT. NBR 12653: Materiais Pozolânicos. Rio de Janeiro: ABNT, 2003.

16. American Society for Testing and Materials - ASTM. C 61812a: Standard for Coal Fly Ash and Raw or Calcined Natural Pozzolan for Use in Concrete. ASTM; 2012.

17. Associação Brasileira de Normas Técnicas-ABNT. NBR 8491: Tijolo maciço de solo-cimento, Especificação. Rio de Janeiro: ABNT, 1984.

18. Neves CMM. Desempenho de paredes: Procedimento adotado para paredes monolíticas de solo-cimento. Camaçari Centro de Pesquisas e Desenvolvimento - CEPED, 2008.

19. Associação Brasileira de Normas Técnicas - ABNT. NBR 13553: Materiais para emprego em parede monolítica de solo-cimento sem função estrutural. Rio de Janeiro: ABNT, 1996. 